\title{
Changes in the composition of juice expressed from Camembert cheese during ripening
}

\author{
Rachel Boutrou*, Frédéric Gaucheron, Michel Piot, \\ Françoise Michel, Jean-Louis Maubois, Joëlle Léonil
}

Laboratoire de recherches de technologie laitière, Inra, 65, rue de Saint-Brieuc, 35042 Rennes cedex, France

(Received 17 December 1998; accepted 22 April 1999)

\begin{abstract}
Cheese can be considered as a paracasein network including fat and aqueous phases. Changes in the composition of the aqueous phase reflect the enzymatic and physico-chemical phenomena that occur in cheese during ripening. For the first time, juice was expressed by pressing from Camembert cheese ripened up to $16 \mathrm{~d}$ and analysed in addition to the cheese to evaluate the extent of proteolysis together with the solubilisation of minerals. The amount of expressable juice decreased sharply during ripening, i.e. from 67 to $19 \%$ of the total water content for cheeses ripened 0 and $16 \mathrm{~d}$, respectively. In parallel, the levels of $\mathrm{pH}$ 4.6-soluble nitrogen and non-protein nitrogen increased in the whole Camembert cheese; the increase was higher in the juice. Simultaneously, the concentration of organic phosphate in the juice increased with concomitant decreases in the concentrations of calcium and inorganic phosphate. This last observation suggests that salt precipitates at the surface of the cheese. The expression and subsequent analysis of juice from Camembert cheeses is an appropriate method for following the sequential action of proteolytic enzymes and mineral transfer that occur during ripening. (C) Inra/Elsevier, Paris.
\end{abstract}

soft cheese / aqueous phase / proteolysis / mineral / ripening

Résumé - Composition du jus extrait de camembert au cours de l'affinage. Le fromage peut être considéré comme un réseau de paracaséine incluant les globules gras et une phase aqueuse. L'évolution de la composition de cette phase aqueuse traduit les phénomènes enzymatiques et physico-chimiques qui se produisent dans le fromage au cours de l'affinage. Nous avons modifié les conditions d'extraction décrites pour l'expression par pressage hydraulique de la phase aqueuse des fromages à pâte dure (rapport sable/fromage et cinétique de montée en pression) et réussi pour la première fois à extraire le jus de camembert affiné jusqu'à $16 \mathrm{j}$. La protéolyse (évolution des différentes fractions azotées) et les teneurs en minéraux des jus et des fromages correspondants ont été suivies. La quantité de jus de camembert extrait diminue fortement au cours de l'affinage, représentant de 67 à $19 \%$ de l'eau contenue dans les fromages entre 0 et $16 \mathrm{j}$. Parallèlement, les teneurs en azote soluble à

\footnotetext{
${ }^{*}$ Correspondence and reprints. rboutrou@rennes.inra.fr
} 
$\mathrm{pH} 4,6$ et en azote non protéique augmentent dans le fromage ; cette augmentation est plus forte dans le jus. Sur cette même période, la concentration dans le jus en phosphate organique augmente tandis que les concentrations en calcium et en phosphate inorganique diminuent, suggérant une précipitation sous forme de sels à la surface des fromages. Le suivi de la répartition des composants azotés et minéraux dans le jus et le fromage permet d'affirmer que la caractérisation analytique du jus permet l'étude approfondie de l'action séquentielle des enzymes protéolytiques et des transfert de minéraux se produisant au cours de l'affinage. (c) Inra/Elsevier, Paris.

\section{fromage à pâte molle / phase aqueuse / protéolyse / minéraux / affinage}

\section{INTRODUCTION}

Cheese can be considered in most cases as a biphasic system constituted of a network of paracasein, in which fat globules and bacterial colonies are dispersed, and an aqueous phase. The composition of the aqueous phase changes continuously during ripening due to the activity of the numerous enzymes involved: the indigenous milk enzymes, the rennet enzymes, the extracellular enzymes of bacteria and fungi and the intracellular enzymes resulting from the lysis of lactic acid bacteria [4]. The cheese matrix and the aqueous phase are dynamic systems, the composition of which differs according to the type of cheese and the stage of ripening.

Most of the few studies on the characterisation of the aqueous phase expressed from cheese by pressing, named juice, concern hard cheeses. Studies have been reported on the effect of salt content on proteolysis [19], the partition of lactose, lactic acid and electrolytes between Cheddar curd and whey [15], the salt crystals [16], the buffering properties of Emmental cheese and juice [14], the effects of technological manufacturing parameters and ripening conditions on cheese composition [18], and the dynamics of bacterial populations [20]. However, almost no information is available on juice expressed from semi-hard or soft cheeses due to the technical difficulties encountered in expressing juice from these types of cheeses. Sandberg et al. [19] failed to express juice from Camembert cheese.
Recently, Pierre et al. [17] expressed the liquid fraction from soft goat milk cheese at different stages of ripening by an adjustment of the sand/cheese ratio. Adjustment of the kinetics of the applied pressure enabled us to express juice from Camembert cheese up to $16 \mathrm{~d}$ of ripening. To increase our understanding of proteolysis in Camembert cheese during ripening, this paper reports our first results on the proteolytic and physico-chemical changes that occur in Camembert and juice during ripening.

\section{MATERIALS AND METHODS}

\subsection{Cheese}

Camembert cheeses made from pasteurised milk inoculated with Penicillium spores were supplied by a French manufacturer. Cheeses from a single batch were all collected at one time after brining and ripened at $13{ }^{\circ} \mathrm{C}$ and $95 \%$ humidity for $12 \mathrm{~d}$ and inverted 6 times. Then the cheeses were cooled at $6{ }^{\circ} \mathrm{C}$ for $2 \mathrm{~h}$ before being packed in a cellophane-based film and ripened for a further $4 \mathrm{~d}$ at $6{ }^{\circ} \mathrm{C}$. Cheeses were taken at different times of ripening $(0,2,4,6,8,11,13$ and $16 \mathrm{~d})$ and frozen at $-20^{\circ} \mathrm{C}$ until analysed.

\subsection{Expression of juice from Camembert cheese}

The sand/cheese ratio was calculated as a function of the water content of cheeses according to the method of Pierre et al. [17]: $850 \mathrm{~g}$ of whole frozen cheese were grated and rapidly mixed with $1011 \mathrm{~g}$ of Fontainebleau sand with a grain size between 150-250 $\mu \mathrm{m}$ (Prolabo, 
France), i.e., a 1.19 sand/cheese ratio (w/w). Juice was expressed immediately by pressing at $16^{\circ} \mathrm{C}$ using the hydraulic press described by SalvatBrunaud et al. [18]. For Camembert cheese, the pressure was increased linearly over $3 \mathrm{~h}$ up to 1.6 $\mathrm{MPa}$, and up to $3.5 \mathrm{MPa}$ during the fourth hour, Identical pressing conditions were introduced regardless of the age of the cheese.

\subsection{Biochemical analysis of the cheese}

The $\mathrm{pH}$ was measured before freezing at the centre of the cheese and $6 \mathrm{~mm}$ under the surface using a penetrating electrode (PHC2431) linked to a PHM93 pH-meter (Radiometer, Copenhagen, Denmark). The results presented are the average of two determinations, with a coefficient of variation of $<0.5$ and $<0.8 \%$ respectively for the $\mathrm{pH}$ measured at the centre and beneath the surface of the cheese. Subsequent analyses were performed on grated cheese. Total solids (TS) were determined after dessication for $7 \mathrm{~h}$ at $102-105{ }^{\circ} \mathrm{C}$. For nitrogen determination an aliquot of grated cheese was suspended in a sodium citrate solution, as described by Gripon et al. [8]. Total nitrogen $(\mathrm{TN})$, nitrogen soluble at $\mathrm{pH} 4.6(\mathrm{SN})$ and non-protein nitrogen (NPN) soluble in $12 \%$ trichloroacetic acid were determined by the Kjeldhal method. The results are the average of two determinations, with a coefficient of variation of $<2.2,5.3,0.67$ and $1.8 \%$ respectively for TS, TN, SN and NPN. The concentrations of calcium $(\mathrm{Ca})$, magnesium $(\mathrm{Mg})$ and potassium $(\mathrm{K})$ were determined using atomic absorption spectrometry (AA300 Varian, Les Ulis, France) [2]. Chloride $(\mathrm{Cl})$, inorganic phosphate $\left(\mathrm{P}_{1}\right)$ and lactate were determined by ionic chromatography (Dionex, Jouy-en-Josas, France) [5].

In order to compare the composition of cheese and cheese juice, the results are expressed in $\mathrm{g}$ per $\mathrm{kg}$ of water in cheese, as follows:

$x \mathrm{~g} \cdot \mathrm{kg}^{-1}$ water in cheese $=\mathrm{R}^{*} 1000 /(1000-\mathrm{TS})$

where $\mathrm{R}$ is the result of nitrogen or mineral determination, and TS is $\mathrm{g} \cdot \mathrm{kg}^{-1}$ of cheese.

\subsection{Biochemical analysis of cheese juice}

Immediately after pressing, the $\mathrm{pH}$ of the cheese juice was measured, and the juice sam- ples were stored at $-20^{\circ} \mathrm{C}$. Samples were thawed before analysis by incubating for a few minutes in a $30^{\circ} \mathrm{C}$ water bath.

TS and nitrogen contents (TN, SN and NPN) were determined as previously described for cheese samples, with a coefficient of variation of $<1.4,5.98,1.1$ and $1.4 \%$, respectively. Free amino acids and ammonia were determined on a $3 \%$ sulfonic acid filtrate using a Pharmacia LKBAlpha Plus series 2 amino acid analyser (Pharmacia Biotech., Saclay, France).

A sample of juice, diluted $1: 10$ with $8 \mathrm{~mol} \cdot \mathrm{L}^{-1}$ urea, was mixed with an equal volume of $0.125 \mathrm{~mol} \cdot \mathrm{L}^{-1}$ Tris- $\mathrm{HCl}$, pH 6.8 , containing $4 \%$ (w/v) sodium dodecyl sulphate (SDS), $20 \%$ (v/v) glycerol and $10 \%(\mathrm{v} / \mathrm{v}) \beta$-mercaptoethanol and heated at $100^{\circ} \mathrm{C}$ for $3 \mathrm{~min}$. A sample $(7.5 \mu \mathrm{L})$ was taken for SDS-PAGE according to the procedure of Laemmli [11]. Following electrophoresis, gels were stained with $0.1 \%(\mathrm{w} / \mathrm{v})$ Coomassie blue R250 in $50 \%(\mathrm{v} / \mathrm{v})$ methanol-7\% $(\mathrm{v} / \mathrm{v})$ acetic acid and destained in $15 \%$ methanol-7 \% acetic acid.

$\alpha$-Lactalbumin ( $\alpha$-La) and $\beta$-lactoglobulin $(\beta-\mathrm{Lg})$ were quantified by RP-HPLC analysis (Waters 600E analyser, Milford, MA); the juice was diluted $1: 20$ with buffer $\mathrm{A}(0.106 \%$ trifluoroacetic acid [TFA]), filtered through a $0.45-\mu \mathrm{m}$ filter and a sample of filtrate was injected onto a $\mathrm{C}_{4}$ Vydac column (214TP5415, Touzart \& Matignon, France), Soluble proteins were eluted at $40^{\circ} \mathrm{C}$ using a linear gradient formed from buffer A and buffer B ( $80 \%$ acetonitrile and $0.100 \%$ TFA) as follows: $37-57 \%$ buffer B over $37.5 \mathrm{~min}$ at a flow rate of $1 \mathrm{~mL} \cdot \mathrm{min}^{-1} \cdot \alpha-\mathrm{La}$ (Sigma, Saint-Louis, MO, USA) and $\beta-\mathrm{Lg}$ (Sigma) were used for calibration.

The concentrations of $\mathrm{Ca}, \mathrm{Mg}, \mathrm{Na}, \mathrm{K}, \mathrm{Cl}, \mathrm{P}_{\mathrm{I}}$, citrate and lactate were determined as described for cheese analysis. Total phosphate $\left(\mathrm{P}_{\mathrm{T}}\right)$ concentration was determined colorimetrically according to the IDF method (Standard 33C) [3]. The concentration of organic phosphate $\left(\mathrm{P}_{\mathrm{O}}\right)$ in the juice was calculated as $\mathrm{P}_{\mathrm{T}}$ concentration minus $\mathrm{P}_{\mathrm{I}}$ concentration.

To compare the composition of juice and cheese, the results are expressed in $\mathrm{g}$ per $\mathrm{kg}$ of water in juice as follows:

$$
x \mathrm{~g} \cdot \mathrm{kg}^{-1} \text { water in juice }=\mathrm{R} * 1000 /(1000-\mathrm{TS})
$$

where $\mathrm{R}$ is the result of determination, and TS is expressed as $\mathrm{g} \cdot \mathrm{kg}^{-1}$ of juice. 


\section{RESULTS}

\subsection{Expression of juice from Camembert cheese}

Preliminary experiments showed that it was necessary to adapt the protocol used for Emmental cheeses [18] to the structural and compositional characteristics of Camembert cheese. To avoid bursting of the cheese cloth and consequent leakage of cheese paste into the collecting channels of the cheese press, the rate of pressure increase had to be reduced twice. Thus, juice was successfully expressed from 0-16 d ripened Camembert cheeses, as shown in figure 1. Further optimisation of the pressure increase and the sand/cheese ratio are probably necessary for a more efficient expression of juice, especially from old Camembert cheeses.

During the expression of juice, two fractions were distinguished and were collected separately. The volume of the first fraction, expressed between 0 and $0.5 \mathrm{MPa}(0-5$ bars), decreased as ripening progressed, while the volume of the second fraction, expressed from $0.5 \mathrm{MPa}$ to the end of pressing, was almost constant throughout ripening. Both fractions were analysed. The first fraction was, at all stages of ripening, more concentrated in all determined components than the second fraction. This observation has also been made by Pierre et al. [17] for Sainte Maure cheese. Both fractions changed similarly and the weighted averages of both fractions are presented.

A liquid fat phase was also expressed (up to $\sim 40 \mathrm{~g} \cdot \mathrm{kg}^{-1}$ water in cheese) from 0 -11-d-old cheese. At the latest ripening times (13 and $16 \mathrm{~d}$ ), a semi-solid phase, which looked like the outer part of ripened Camembert, was expressed. This phase caused total fouling of the holes in the hoop and bursting of the cheese cloth. The change in the cheese texture due to proteolysis of

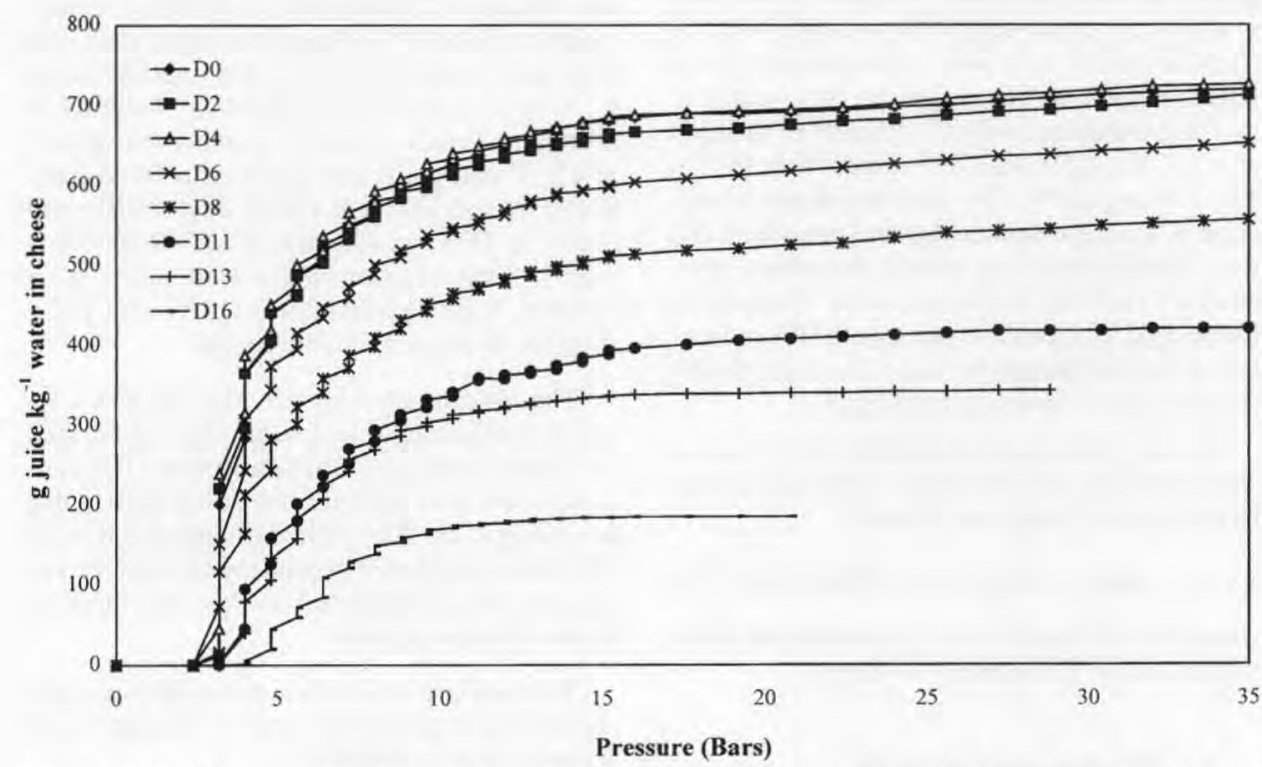

Figure 1. Juice expression from Camembert cheeses at different ripening times as a function of pressure increase.

Figure 1. Expression de jus de camembert au cours de l'affinage. La quantité de jus extraite est exprimée en fonction de la pression appliquée. 
the cheese matrix appears to negatively affect the expression of juice from Camembert cheeses.

The total amount of juice expressed from Camembert cheese decreased during ripening (figure 1): from 740 to $186 \mathrm{~g}$ of juice $\cdot \mathrm{kg}^{-1}$ water in cheese were expressed from cheeses ripened from 0 to $16 \mathrm{~d}$, respectively, representing from 67 to $19 \%$ of the total water contained in the cheeses (figure 2).

\section{2. $\mathrm{pH}$ and proteolysis in cheese and juice}

Changes in the $\mathrm{pH}$ of the cheese measured $6 \mathrm{~mm}$ under the surface and at the centre of the cheese during the ripening period are presented in table I. As described by Le Graët and Brulé [12], the $\mathrm{pH}$ at the centre of the cheese remained at $\sim 4.9-4.8$, whereas the $\mathrm{pH}$ of the outer layer increased after $6 \mathrm{~d}$ of ripening to a final $\mathrm{pH}$ of 6.0 when the Camembert cheeses were $16 \mathrm{~d}$ old. During the ripening period, the $\mathrm{pH}$ of the juice expressed from whole cheese, i.e. a mixture of the core and the surface, increased from 4.9 to 5.7 (table I), thus showing a similar change to that of the outer part of the cheese.

The level of TS in the cheese (table I) increased from 460 to $523 \mathrm{~g} \cdot \mathrm{kg}^{-1}$ during the first $13 \mathrm{~d}$ of ripening and then stabilised due to the wrapping of the cheeses. Such a decrease in water content in cheeses, mainly due to evaporation in the ripening room, corresponds to a $14.2 \%$ concentration of the cheese constituents.

To compare proteolysis in the juice and in the cheese, the nitrogen contents in juice are expressed per unit of water in the juice, and their concentration in cheese per unit of water in the cheese. TN increased from 357 to $470 \mathrm{~g} \cdot \mathrm{kg}^{-1}$ water in cheese, i.e. a relative increase of $32 \%$ over $16 \mathrm{~d}$. SN represented $6 \%$ of the TN in fresh cheese, increased slightly to $8.7 \%$ of the $\mathrm{TN}$ in 4-d-old cheeses and rose sharply to $20 \%$ after $6 \mathrm{~d}$ of ripening (table $I I)$, when the Penicillium completely covered the cheese

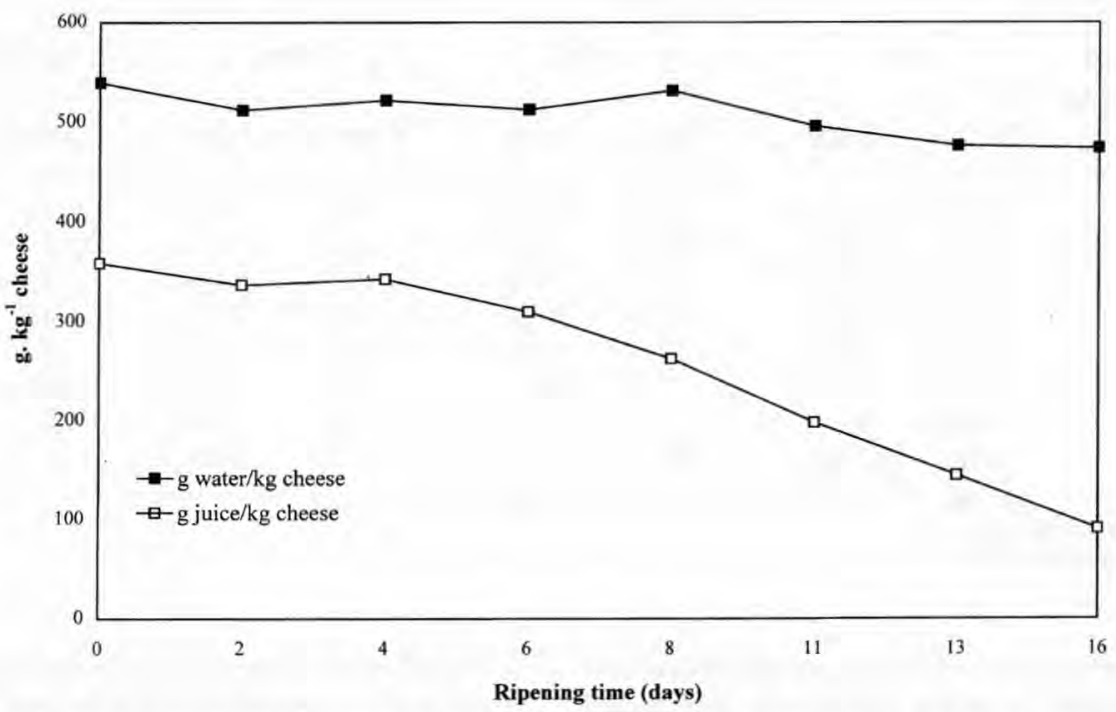

Figure 2. Water content in Camembert cheese ( $1000-$ TS) over the ripening period and the amount of juice expressed from the cheese.

Figure 2. Évolution au cours du temps d'affinage de la quantité d'eau dans le fromage (calculée à partir de l'extrait sec) et de la quantité de jus extraite de ces fromages. 
Table I. Change in $\mathrm{pH}$ and total solids in Camembert cheese and corresponding juice (TS expressed in $\mathrm{g} \cdot \mathrm{kg}^{-1}$ of cheese and juice respectively) during the ripening period.

Tableau I. Évolution au cours de l'affinage du $\mathrm{pH}$ et des extraits secs du camembert et du jus correspondant (TS, exprimé en $\mathrm{g} \cdot \mathrm{kg}^{-1}$ de fromage ou de jus respectivement).

\begin{tabular}{|c|c|c|c|c|c|}
\hline \multirow{2}{*}{$\begin{array}{l}\text { Day of } \\
\text { ripening }\end{array}$} & \multicolumn{3}{|c|}{ Camembert cheese } & \multicolumn{2}{|c|}{ Juice } \\
\hline & $\mathrm{pH}$ surface & $\mathrm{pH}$ centre & $\mathrm{TS}\left(\mathrm{g} \cdot \mathrm{kg}^{-1}\right)$ & $\mathrm{pH}$ & $\mathrm{TS}\left(\mathrm{g} \cdot \mathrm{kg}^{-1}\right)$ \\
\hline 0 & 4.87 & 4.88 & 461 & 4.99 & 115 \\
\hline 2 & 4.91 & 4.86 & 488 & 4.90 & 121 \\
\hline 4 & 4.83 & 4.78 & 478 & 4.85 & 124 \\
\hline 6 & 4.82 & 4.76 & 488 & 4.95 & 129 \\
\hline 8 & 4.94 & 4.80 & 469 & 5.25 & 129 \\
\hline 11 & 5.30 & 4.78 & 504 & 5.43 & 139 \\
\hline 13 & 5.76 & 4.81 & 524 & 5.55 & 147 \\
\hline 16 & 6.00 & 4.86 & 526 & 5.71 & 163 \\
\hline
\end{tabular}

Table II. Change of nitrogen components (TN: total nitrogen, SN: soluble nitrogen at pH 4.6, NPN: non protein nitrogen and free amino acids) in Camembert cheese and corresponding juice throughout the ripening period. Results are expressed in $\mathrm{g} \cdot \mathrm{kg}^{-1}$ water in cheese and $\mathrm{g} \cdot \mathrm{kg}^{-1}$ water in juice respectively.

Tableau II. Évolution au cours de l'affinage des composants azotés (TN : azote total, SN : azote soluble à $\mathrm{pH} 4.6, \mathrm{NPN}$ : azote non protéique et de la somme des acides aminés libres) dans le camembert et le jus correspondant. Les résultats sont exprimés respectivement en $\mathrm{g} \cdot \mathrm{kg}^{-1} \mathrm{~d}$ 'eau dans le fromage et en $\mathrm{g} \cdot \mathrm{kg}^{-1}$ d'eau dans le jus.

\begin{tabular}{|c|c|c|c|c|c|c|c|}
\hline \multirow{2}{*}{$\begin{array}{l}\text { Day of } \\
\text { ripening }\end{array}$} & \multicolumn{2}{|c|}{$\mathrm{TN}$} & \multicolumn{2}{|c|}{$\mathrm{SN}$} & \multicolumn{2}{|c|}{ NPN } & \multirow{2}{*}{$\frac{\text { Amino acids }}{\text { Juice }}$} \\
\hline & Cheese & Juice & Cheese & Juice & Cheese & Juice & \\
\hline 0 & 357.0 & 31.4 & 22.3 & 21.0 & 10.7 & 8.7 & 1.4 \\
\hline 2 & 386.8 & 35.0 & 30.4 & 25.8 & 13.2 & 11.7 & 1.8 \\
\hline 4 & 382.1 & 37.6 & 33.2 & 31.1 & 16.3 & 14.6 & 2.1 \\
\hline 6 & 377.5 & 48.5 & 72.9 & 42.6 & 38.2 & 27.5 & 4.5 \\
\hline 8 & 359.6 & 59.5 & 73.0 & 52.2 & 46.7 & 36.2 & 7.3 \\
\hline 11 & 411.8 & 78.2 & 77.7 & 66.2 & 47.7 & 39.1 & 10.8 \\
\hline 13 & 462.1 & 93.4 & 87.4 & 75.9 & 52.0 & 38.9 & 10.7 \\
\hline 16 & 470.2 & 111.8 & 92.4 & ND & 53.7 & ND & 14.5 \\
\hline
\end{tabular}

ND: not determined.

ND : non déterminé.

surface. The SN/TN ratio remained constant thereafter. A similar change was determined in the NPN/TN ratio, which varied from 3 to $4.3 \%$ in fresh cheeses (from 0 to $4 \mathrm{~d}$ of ripening), reached $11 \%$ at $\mathrm{d} 6$ and then remained constant.
The TS of the juice showed an increase of 21 and $42 \%$ respectively after 11 and $16 \mathrm{~d}$ of ripening (table I). Increases of juice TN for the same two ripening stages were 149 and $256 \%$, respectively (table $I I$ ). The $\mathrm{SN} / \mathrm{TN}$ ratio increased until $8 \mathrm{~d}$ of ripening 
(from 0.67 to 0.88 ) and then decreased slightly (up to 0.81 at $\mathrm{d} 13$ ). The same general tendency was observed for the NPN/TN ratio (from 0.28 to 0.61 at $8 \mathrm{~d}$, and a subsequent decrease to 0.42 ). The concentration of amino acids (including $\mathrm{NH}_{3}$ ) showed the greatest increase. The concentration of most amino acids increased during ripening, except that concerning asparagine, which was not present in the juice expressed from 8-d-old cheeses (figure 3). Compared to the earlier stage of ripening there was a significant increase in the concentration of methionine expressed from 11-d-old cheese, but it did not increase further after this stage of ripening. The concentration of ammonia showed a sharp increase between 8 and $11 \mathrm{~d}$.

The electrophoretic profiles also showed the extent of proteolysis in the cheese by analysis of the juice (figure 4). From 0 to $4 \mathrm{~d}$ of ripening, the profiles were identical and showed the presence of intact $\alpha_{\mathrm{s}}$ - and $\beta$-caseins in the juice. The profiles changed at $\mathrm{d} 6$ and $\mathrm{d} 8$, notably with the lower level of intact caseins and numerous bands arising from the degradation of caseins. The profiles did not change thereafter.

The concentrations of $\alpha-\mathrm{La}$ and $\beta-\mathrm{Lg}$ in the juice were also quantified. During ripening, the concentration of $\alpha$-La remained constant during the first $4 \mathrm{~d}$ of ripening $\left(1.4 \mathrm{~g} \cdot \mathrm{kg}^{-1}\right.$ water in the juice) and then decreased $\left(0.4 \mathrm{~g} \cdot \mathrm{kg}^{-1}\right.$ water in the juice at $16 \mathrm{~d})$. The concentration of $\beta$ - $\mathrm{Lg}$ increased slightly throughout the ripening period, i.e. from 4.2 to $5.7 \mathrm{~g} \cdot \mathrm{kg}^{-1}$ water in the juice. These values, which were lower than those usually present in milk, confirm that the milk used to make the Camembert cheeses was heat-treated.

\subsection{Mineral analysis of the juice}

The results for mineral determinations on the cheese and on the juice are respectively presented in table III. In cheese, the concentrations of $\mathrm{Ca}, \mathrm{Mg}, \mathrm{P}_{\mathrm{I}}, \mathrm{K}$ and $\mathrm{Cl}$ increased slightly from 0 to $6-8 \mathrm{~d}$ of ripen-

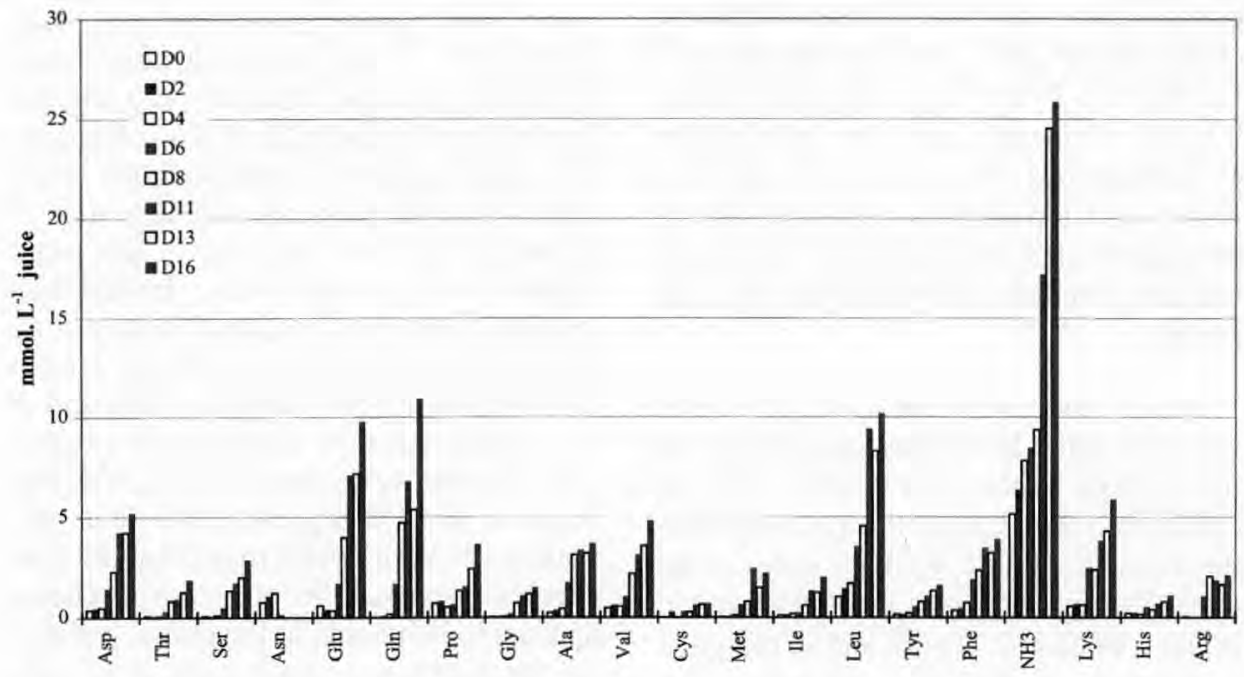

Figure 3. Change in amount of amino acids and ammonia in the juice expressed from Camembert cheeses at different ripening times.

Figure 3. Évolution des quantités d'acides aminés et d'ammoniaque dans le jus extrait de camembert à différents temps d'affinage. 


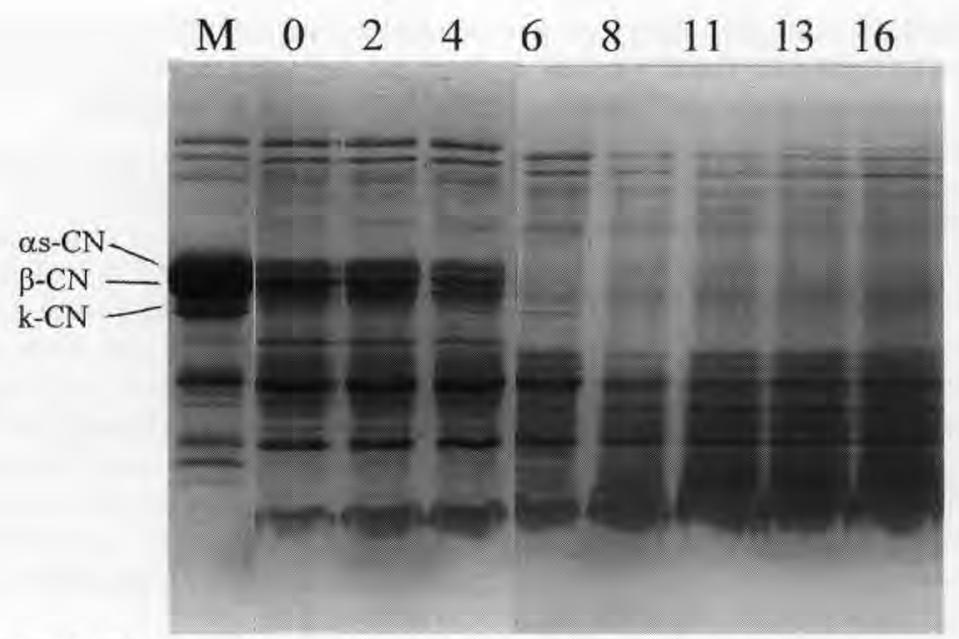

Figure 4. SDS-PAGE analysis of reconstituted milk powder (lane M) and juice expressed from Camembert cheese at different ripening stages (lanes 0-16, numbers refer to the ripening time in d).

Figure 4. Électrophorégramme SDS-PAGE d'un lait en poudre reconstitué (ligne M) et des jus extraits de camembert à différents temps d'affinage (lignes $0-16$, les numéros correspondant au temps d'affinage en $\mathrm{j}$ ).

ing, and thereafter increased more rapidly until d 16. The concentration of lactate also increased during the early stages of ripening, but then decreased until the end of ripening (table III). In juice, the concentrations of $\mathrm{Ca}, \mathrm{Mg}, \mathrm{P}_{\mathrm{T}}, \mathrm{P}_{1}$ and lactate increased from 0 to $4 \mathrm{~d}$ of ripening and then decreased to $16 \mathrm{~d}$ of ripening. The concentrations of $\mathrm{P}_{\mathrm{O}}$, $\mathrm{K}, \mathrm{Na}$ and $\mathrm{Cl}$ in the juice increased slightly throughout ripening (table III). No citrate was detected in the juice during the ripening period.

At $\mathrm{d} 0(\mathrm{pH}=4.9)$, the $\mathrm{Ca} / \mathrm{P}_{\mathrm{I}}$ mass ratio was 0.91 and 0.88 in the cheese and in the juice, respectively. At d $4(\mathrm{pH}=4.8)$, the concentrations of $\mathrm{Ca}$ and $\mathrm{P}_{\mathrm{I}}$ were maximal in the juice $\left(6.2\right.$ and $6.5 \mathrm{~g} \cdot \mathrm{kg}^{-1}$ water in the juice) and the $\mathrm{Ca} / \mathrm{P}_{\mathrm{I}}$ ratio was 0.84 and 0.95 in the Camembert cheese and in the juice, respectively. At this stage of ripening, 1/3 of $\mathrm{Ca}$ and $1 / 2$ of $\mathrm{P}_{1}$ were present in the casein matrix. After $4 \mathrm{~d}$, the $\mathrm{Ca} / \mathrm{P}_{\mathrm{I}}$ ratio remained unchanged in the cheese $(0.86$ at $\mathrm{d} 16)$, but decreased to 0.85 in the juice.

\section{DISCUSSION AND CONCLUSION}

The juice occluded in the matrix of the Camembert cheese can be expressed by an adaptation of the pressing conditions described for hard cheeses [18] and for Sainte Maure cheese [17]. Water in Camembert cheese appears to be less readily available than that in hard cheeses such as Emmental, or even than that in soft lactic cheeses such as Sainte Maure. Indeed, Salvat-Brunaud et al. [18] and Thierry et al. [20] also observed a decrease in the amount of expressable juice during the ripening of Emmental, but they were able to express $\sim 30 \%$ of the water from 60 -d-old cheeses. Pierre et al. [17] expressed the same proportion $(33 \%)$ of water from 58 -d-old goat cheeses. Expressability of juice from cheese appears to be related to the cheese variety, i.e. the curd type (rennet, lactic or mixed), the curd treatments (stirring, cooking, pressing, etc.) and to the stage of ripening.

During the first $4 \mathrm{~d}$ of ripening, the fermentation of lactose to lactate by lactic acid 
Table III. Change in mineral composition of Camembert cheese and of the corresponding juice as a function of ripening time. Results are expressed in $\mathrm{g} \cdot \mathrm{kg}^{-1}$ water in cheese and $\mathrm{g} \cdot \mathrm{kg}^{-1}$ water in juice respectively. Organic phosphate $\left(\mathrm{P}_{\mathrm{O}}\right)$ concentration in juice was calculated as total phosphate $\left(\mathrm{P}_{\mathrm{T}}\right)$ minus inorganic phosphate $\left(\mathrm{P}_{\mathrm{I}}\right)$ concentrations.

Tableau III. Évolution au cours de l'affinage de la composition minérale du camembert et du jus correspondant. Les résultats sont exprimés respectivement en $\mathrm{g} \cdot \mathrm{kg}^{-1} \mathrm{~d}$ 'eau dans le fromage et en $\mathrm{g} \cdot \mathrm{kg}^{-1}$ d'eau dans le jus. La concentration du phosphate organique $\left(\mathrm{P}_{\mathrm{O}}\right)$ dans le jus a été calculée par soustraction de la teneur en phosphate inorganique $\left(\mathrm{P}_{\mathrm{I}}\right)$ à la teneur en phosphate total $\left(\mathrm{P}_{\mathrm{T}}\right)$.

\begin{tabular}{|c|c|c|c|c|c|c|c|c|c|c|c|c|c|c|c|}
\hline \multirow{2}{*}{$\begin{array}{l}\text { Day of } \\
\text { ripening }\end{array}$} & \multicolumn{2}{|c|}{$\mathrm{Ca}$} & \multicolumn{2}{|c|}{$\mathrm{Mg}$} & \multicolumn{2}{|c|}{$\mathrm{K}$} & \multirow{2}{*}{$\begin{array}{c}\mathrm{Na} \\
\text { Juice }\end{array}$} & \multirow{2}{*}{$\begin{array}{c}\mathrm{P}_{\mathrm{T}} \\
\text { Juice }\end{array}$} & \multicolumn{2}{|c|}{$P_{I}$} & \multirow{2}{*}{$\begin{array}{c}\mathrm{P}_{0} \\
\text { Juice }\end{array}$} & \multicolumn{2}{|c|}{$\mathrm{Cl}$} & \multicolumn{2}{|c|}{ Lactate } \\
\hline & Cheese & Juice & Cheese & Juice & Cheese & Juice & & & Cheese & Juice & & Cheese & Juice & Cheese & Juice \\
\hline 0 & 9.7 & 5.5 & 0.4 & 0.3 & 2.8 & 2.2 & 11.6 & 7.1 & 10.7 & 6.2 & 0.9 & 20.7 & 16.3 & 32.6 & 23.4 \\
\hline 2 & 10.2 & 5.8 & 0.4 & 0.5 & 2.5 & 2.4 & 12.1 & 6.5 & 11.8 & 5.6 & 0.9 & 18.1 & 17.9 & 41.6 & 27.2 \\
\hline 4 & 10.2 & 6.2 & 0.4 & 0.6 & 2.4 & 2.4 & 11.8 & 7.7 & 12.1 & 6.5 & 1.2 & 20.1 & 17.2 & 44.5 & 27.5 \\
\hline 6 & 10.3 & 6.1 & 0.4 & 0.6 & 2.5 & 2.6 & 12.9 & 7.3 & 11.7 & 5.8 & 1.4 & 20.8 & 19.4 & 38.9 & 27.1 \\
\hline 8 & 10.6 & 4.7 & 0.4 & 0.3 & 2.6 & 2.6 & 13.9 & 6.4 & 10.9 & 4.8 & 1.6 & 23.7 & 21.6 & 23.0 & 19.2 \\
\hline 11 & 11.5 & 4.2 & 0.5 & 0.3 & 3.1 & 2.9 & 15.0 & 6.2 & 13.4 & 4.0 & 2.2 & 23.7 & 24.3 & 26.5 & 16.9 \\
\hline 13 & 12.3 & 3.6 & 0.4 & 0.3 & 3.0 & 2.9 & 14.8 & 6.1 & 15.2 & 3.9 & 2.2 & 30.1 & 34.6 & 14.7 & 14.0 \\
\hline 16 & 13.8 & 3.3 & 0.6 & 0.3 & 3.5 & 3.1 & 16.0 & 6.3 & 16.0 & 3.9 & 2.4 & 25.7 & 26.6 & 23.4 & 11.7 \\
\hline
\end{tabular}


bacteria continues and the $\mathrm{pH}$ consequently decreases. This acidification leads to the solubilisation of $\mathrm{Ca}, \mathrm{Mg}, \mathrm{P}_{\mathrm{T}}, \mathrm{P}_{1}$ and $\mathrm{P}_{\mathrm{O}}$ (Brulé et al.[2]; Le Graët et al. [13]) from the casein network into the aqueous phase. The relatively high proportion of $\mathrm{SN}$ components and the electrophoretic profiles indicate the predominance of large casein fragments generated under the action of the rennet enzymes [21].

The aqueous phase becomes less expressable after $\mathrm{d} 6$ of ripening (figure 1), when the $\mathrm{pH}$ of the outer layer of the cheese starts to increase due to the growth and the metabolic activity of the surface mould Penicillium, i.e. the degradation of lactate [6] and a notable ammonia production which, in spite of the high buffering capacity of the juice $\left(5.07 \mathrm{~g} \cdot \mathrm{kg}^{-1}\right.$ of $\left.\mathrm{P}_{\mathrm{I}}\right)$, causes an increase in $\mathrm{pH}$. A similar change of SN and NPN in cheese and in juice, marked by a large increase from $6 \mathrm{~d}$ of ripening, confirms that the cheese juice is a good indicator of the proteolytic mechanisms occurring during the ripening of Camembert cheese. Apart from the whey proteins, which mainly remain intact, the TN of the juice appears to be a complex mixture of large casein fragments which are insoluble at $\mathrm{pH} 4.6$, medium and small peptides, free amino acids and ammonia compounds. The large increase in NPN components in the juice, i.e. from $\sim 30-35 \%$ of $\mathrm{TN}$ at $\mathrm{d} 0-4$ rising to $61 \%$ at $\mathrm{d} 8$, indicates the appearance of small and medium peptides and suggests the predominant action, from 6-8 d of ripening, of the microbial proteinases and peptidases of Penicillium [7]. The activity of the peptidases from $6 \mathrm{~d}$ of ripening is confirmed by the higher proportion of amino acids in TN. Most of the increase in the cheese TS results from the evaporation of water in the ripening rooms, but a relatively significant part is also caused by proteolysis itself. Indeed, each breakdown of a peptidic bond consumes one water molecule.

The $\mathrm{pH}$ increase at the surface of the cheese leads to the precipitation of differ- ent salts. In the juice, the decrease in the weighed ratio $\mathrm{Ca} / \mathrm{P}_{\mathrm{I}}$, from $\sim 0.95$ at $\mathrm{d} 4$ to 0.85 at $\mathrm{d} 16$, is probably related to the precipitation of $\mathrm{Ca}$ in higher amounts than inorganic phosphate at the surface of the cheese, given that the precise composition of salt precipitating at the rind of the Camembert cheese remains unknown. It could be composed of tricalcic phosphate or magnesium phosphate (Brooker [1]; Holt [9]; Le Graët et al. [13]). In parallel with the decrease in the concentrations of $\mathrm{Ca}, \mathrm{Mg}, \mathrm{P}_{\mathrm{T}}$ and $\mathrm{P}_{\mathrm{I}}$ in the juice from $\mathrm{d} 4$ to $\mathrm{d} 16$, the organic phosphate concentration increased during ripening, indicating proteolysis of the paracasein network with the release of phosphorylated peptides into the juice. However, the exact nature (phosphoserine or phosphopeptide) and origin ( $\alpha_{\mathrm{s} 1^{-}}, \alpha_{\mathrm{s} 2^{-}}$and $\beta$-caseins) of the organic phosphate cannot be determined by the method used. As the phosphopeptides bind strongly to divalent cations such as $\mathrm{Ca}$ and $\mathrm{Mg}$, it is possible that $\mathrm{Ca}$ and $\mathrm{Mg}$ bound to phosphopeptides were also released into the juice. However, this phenomenon, leading to an increase in ionic concentration in the juice, seems to be of less importance than the precipitation phenomenon since the global result was a depletion of $\mathrm{Ca}$ and $\mathrm{Mg}$ in the juice. The linear increase in the concentrations of $\mathrm{K}$ and $\mathrm{Cl}$ in the water of the cheese and in the water of the juice indicates that these elements remain soluble within the cheese throughout the ripening. Identical results have been reported for Cheddar (Morris et al. [16]) and Mozzarella cheese (Kindstedt and Guo [10]) concerning $\mathrm{Na}$ and $\mathrm{K}$.

Further work is required to identify the products of proteolysis and thus to quantify the degradation of the paracasein network, and to clarify the mechanisms responsible for strong water binding during ripening, which may be due to proteolysis of the casein matrix or to changes in the partition of salts. In other respects, separate analysis of the juice expressed from the centre of the cheese will allow assessment of the ripening effects caused by the surface flora. 


\section{ACKNOWLEDGEMENT}

We thank A. Pierre for helpful suggestions regarding the manuscript.

\section{REFERENCES}

[1] Brooker B.E., The crystallization of calcium phosphate at the surface of mould-ripened cheeses, Food Microstruct. 6 (1987) 25-33.

[2] Brulé G., Maubois J.L., Fauquant J., Étude de la teneur en éléments minéraux des produits obtenus lors de l'ultrafiltration du lait sur membrane, Lait 54 (1974) 600-615.

[3] FIL, Fromages et fromages fondus. Détermination de la teneur en phosphore total : méthode photométrique, Standard FIL-IDF 33C, Bruxelles, 1987.

[4] Fox P.F., Wallace J.M., Morgan S., Lynch C.M., Niland E.J., Tobin J., Acceleration of cheese ripening, Antonie van Leeuwenhoek 70 (1996) 271-297.

[5] Gaucheron F., Piot M., Boyaval E., Determination of anions of milk by ion chromatography, Lait 76 (1996) 433-443.

[6] Gripon J.C., Mould-ripened cheeses, in: Fox P.F. (Ed.), Cheese: Chemistry, Physics and Microbiology, Vol. 2. Major Cheese Groups, Elsevier, London, 1993, pp. 111-136.

[7] Gripon J.C., Desmazeaud M., Le Bars D., Role of proteolytic enzymes of Streptococcus lactis, Penicillium roqueforti and Penicillium caseicolum during cheese ripening, J. Dairy Sci. 60 (1977) 1532-1538.

[8] Gripon J.C., Desmazeaud M., Le Bars D., Bergere J.L., Étude du rôle des microorganismes et de leurs enzymes dans la maturation des fromages, II. Influence de la présure commerciale, Lait 55 (1975) 502-516.

[9] Holt C., Effect of heating and cooling on the milk salts and their interaction with casein, in: IDF (Ed.), Heat-induced Changes in Milk, 2nd Ed., special issue 9501 (1995) 105-133.

[10] Kindstedt P.S., Guo M.R., A physico-chemical approach to the structure and function of Mozzarella cheese, Aust. J. Dairy Technol. 53 (1998) $70-73$.
[11] Laemmli U.K., Cleavage of structural proteins during the assembly of the head of bacteriophage T4, Nature (Lond.) 227 (1970) 680-685.

[12] Le Graët Y., Brulé G., Migration des macro-et oligo-éléments dans un fromage à pâte molle de type camembert, Lait 68 (1988) 219-234.

[13] Le Graët Y., Lepienne A., Brulé G., Ducruet P., Migration du calcium et des phosphates inorganiques dans les fromages à pâte molle de type camembert au cours de l'affinage, Lait 63 (1983) 317-332.

[14] Lucey J.A., Fox P.F., Importance of calcium and phosphate in cheese manufacture: a review, J. Dairy Sci. 76 (1993) 1714-1724.

[15] McDowall F.G., Dolby R.M., Studies on the chemistry of Cheddar cheese making. IV. Lactose and lactic acid in whey and curd; the presence of bound water in curd; the existence of a Donnan equilibrium between curd and whey; and the rate of penetration of salt into curd, J. Dairy Res. 7 (1936) 156-174.

[16] Morris H.A., Holt C., Brooker B.E., Banks J.M., Manson W., Inorganic constituents of cheese: analysis of juice from one-month-old Cheddar cheese and the use of light and electron microscopy to characterize the crystalline phases, J. Dairy Res. 55 (1988) 255-268.

[17] Pierre A., Michel F., Le Graët Y., Berrier J., Soft goat cheeses at different ripening stages: cheese structure, composition and non solvent water, Lait 79 (1999), 489-501.

[18] Salvat-Brunaud D., Maubois J.L., Maillard M.B., Corre C., Thierry A., Expression et analyse de la phase aqueuse de l'emmental à quatre stades d'affinage, Lait 75 (1995) 239-249.

[19] Sandberg E., Haglund E., Barthel C, L'analyse du jus de fromage comme moyen de déterminer le degré de maturation, Lait 10 (1930) 1-21.

[20] Thierry A., Salvat-Brunaud D., Madec M.N., Michel F., Maubois J.L., Affinage de l'Emmental : dynamique des populations bactériennes et évolution de la composition de la phase aqueuse, Lait 78 (1998) 521-542.

[21] Trieu-Cuot P., Gripon J.C., A study of proteolysis during cheese ripening using isoelectric focusing and two-dimensional electrophoresis, J. Dairy Res. 49 (1982) 501-510. 